\title{
Kebijakan Upsus Pajale: Mampukah Menambah Provinsi Basis Produksi Pajale?
}

\section{Upsus Pajale Policy: Is It Able To Increase The Pajale Production Base Province?}

\author{
Dany Juhandi ${ }^{1 *}$, Ambo Enre ${ }^{2}$ \\ ${ }^{1 *}$ Program Studi Agribisnis Hortikultura, Politeknik Wilmar Bisnis Indonesia, Jl. Kapten Batu Sihombing, \\ Medan Estate, Deli Serdang, Sumatera Utara 20371, Indonesia \\ ${ }^{2}$ Program Studi Akuntansi Perpajakan, Politeknik Wilmar Bisnis Indonesia, Jl. Kapten Batu Sihombing, \\ Medan Estate, Deli Serdang, Sumatera Utara 20371, Indonesia
}

Diterima: 12 Oktober 2019; Direvisi: 5 November 2019; Disetujui: 1 Desember 2019

\begin{abstract}
ABSTRAK
Berbagai kebijakan untuk mencapai swasembada pangan sudah dilakukan sejak era pemerintahan Presiden Soekarno hingga Presiden Joko Widodo. Namun, hanya kebijakan era Presiden Soeharto yang mampu swasembada beras. Pada era Presiden Joko Widodo melalui Kementerian Pertanian mengeluarkan peraturan Menteri Pertanian No.14 Tahun 2015 untuk mempercepat swasembada padi, jagung dan kedelai dalam empat tahun. Dengan adanya kebijakan tersebut hampir seluruh provinsi di Indonesia didorong untuk meningkatkan produksi padi, jagung dan kedelai. Namun sampai saat ini tujuan swasembada tersebut belum mampu tercapai. Penelitian ini bertujuan untuk (1) menganalisis provinsi-provinsi yang menjadi basis komoditi pajale sebelum dan setelah program UPSUS Pajale, (2) menganalisis terjadinya penyebaran dan pemusatan produksi komoditi pajale sebelum dan setelah program UPSUS Pajale, dan (3) menganalisis provinsi-provinsi yang menjadi prioritas komoditi pajale sebelum dan setelah UPSUS Pajale. Penelitian ini menggunakan metode deskriptif kuantitatif dengan menggunakan data sekunder tahun 2012 - 2017. Alat analisis yang digunakan yaitu Location Quotien, Specialization and Localization Quotien. Dari hasil penelitian ditemukan bahwa (1) Terjadi penambahan provinsi basis produksi pajale setelah adanya program UPSUS Pajale, (2) hampir di semua provinsi tidak terjadi spesialisasi dan pemusatan produksi komoditi pajale setelah adanya program UPSUS Pajale, dan (3) Provinsi-provinsi yang menjadi prioritas komoditi pajale tidak banyak berubah baik sebelum dan setelah adanya program UPSUS Pajale.
\end{abstract}

Kata kunci: upsus pajale; swasembada

\section{ABSTRACT}

Various policies to achieve food self-sufficiency have been carried out since the era of President Soekarno to Joko Widodo. However, only President Soeharto's era policies were capable in rice selfsufficiency. In the era of President Joko Widodo through the Ministry of Agriculture issued Minister of Agriculture Regulation No. 14 of 2015 to accelerate self-sufficiency in rice, maize, and soybeans in four years. With this policy, almost all provinces in Indonesia are encouraged to increase production of rice, maize, and soybean. But, the goal of self-sufficiency has not been able to be achieved. This study aims to (1) analyze the provinces that are being the basis of pajale commodities before and after the UPSUS PAJALE program, (2) analyze the distribution and concentration of pajale commodity production before and after the UPSUS Pajale program, and (3) analyze the provinces which a priority in pajale commodity development before and after UPSUS Pajale. This study uses quantitative descriptive methods using secondary data in 2012 - 2017. The analysis tools used are Location Quotien, Specialization and Localization Quotion. The results of the study shown that (1) An increase in the province of pajale production bases after the UPSUS Pajale program, (2) almost all provinces were spread and there was no concentration of pajale commodity production after the UPSUS Pajale program, and (3) Provinces that being a pajale commodity priority has not changed much before and after the UPSUS Pajale program.

Keywords: upsus pajale; self-sufficiency 


\section{How to Cite:}

Juhandi, D., \& Enre, A. (2019). Kebijakan Upsus Pajale: Mampukah Menambah Provinsi Basis Produksi Pajale ? Habitat, 30(3), 123-131. https://doi.org/10.21776/ub.habitat.2019.030.3.15

\section{Pendahuluan}

Komoditi pangan mendapatkan perhatian khusus oleh pemerintah Indonesia. Sejak presiden pertama Indonesia, Soekarno, kebutuhan pangan untuk rakyat Indonesia harus terpenuhi tanpa bergantung dari impor. Silih-berganti era pemerintahan, baru era pemerintahan Soeharto yang mampu memenuhi kebutuhan pangan utama penduduk Indonesia yaitu beras dengan swasembada beras tanpa melakukan impor beras.

Presiden Soeharto mampu mencapai swasembada beras melalui beberapa program seperti menambah tugas dan peran bulog, penetapan harga dasar dan revolusi hijau (Jonatan Lassa, 2010).

Namun swasembada beras pada waktu itu hanya mampu bertahan sekitar 5 tahun saja (Simatupang \& Rusastra, 2004). Setelah era pemerintahan Soeharto hingga kini Indonesia belum mampu mencapai kembali swasembada meskipun banyak program yang telah dibuat untuk mencapainya.

Swasembada pangan khususnya beras sangat sulit untuk dicapai karena ada beberapa tantangan yang harus dihadapi oleh pemerintah, salah satunya adalah konversi lahan sawah. Karena konversi lahan sawah ke non sawah akan menyebabkan luas lahan padi berkurang yang berdampak pada penurunan produksi. Konversi lahan sawah tahun 1999 - 2002 sebanyak 563.000 ha, lahan sawah dialihfungsikan menjadi areal perumahan, perindustrian dan perkebunan (Sawit, 2013).

Di tengah gencarnya konversi lahan, meskipun jumlah produksi beras meningkat, tetapi peningkatan tersebut tidak melebihan peningkatan konsumsi beras sehingga pemerintah perlu melakukan impor beras. Konsumsi lebih tinggi dibandingkan produksi, seperti pada tahun 2010 - 2014 produksi beras meningkat 4,4juta ton sedangkan pada tahun yang sama pertumbuhan penduduk meningkat 13,7 juta jiwa dengan tingkat konsumsi beras per kapita $1,73 \mathrm{~kg} / \mathrm{minggu}$ (Siswanto, Marulitua Sinaga, \& Harianto, 2018).

\footnotetext{
*Penulis Korespondensi

E-mail: danyjuhandi@outlook.com

Telp: +62-852-7893-0707
}

Pada tahun 2012 -2016 yang menjadi sentral produksi padi nasional yaitu Provinsi Jawa Timur, Jawa Tengah dan Jawa Barat dengan rata-rata kontribusi produksi nasional sebesar 14 persen (Kementan, 2016). Beberapa sentral produksi padi tersebut harus memenuhi kebutuhan beras yang menjadi makanan pokok penduduk Indonesia lebih dari 240juta jiwa. Tentu dengan jumlah produksi seperti itu tidak mampu untuk memenuhi kebutuhan seluruh penduduk. Maka diperlukan impor untuk memenuhi kebutuhan tersebut.

Jika impor komoditi pangan tersebut terus dilakukan tentu akan membebani neraca perdagangan dan neraca pembayaran. Karena kegiatan ekspor dan impor memiliki korelasi yang kuat terhadap neraca perdagangan dan pembayaran (Wiryanti, 2015). Dan juga ironis jika sebenarnya Indonesia mampu memproduksi komoditi tersebut yang secara geografis dan iklim sangat sesuai tetapi harus melakukan impor komoditi tersebut.

Saat ini era Pemerintahan Joko Widodo, ada upaya khusus yang dinamakan UPSUS Pajale yang melibatkan banyak pihak untuk mencapai swasembada seperti akademisi, Tentara Nasional Indonesia (TNI), pemerintah dan tentunya petani (Utami, 2015)(Nabawi, 2016). Semua pihak berusaha untuk mencapai tujuan UPSUS Pajale seperti yang tertuang dalam Peraturan Kementerian Pertanian No. 14 Tahun 2015.

Beberapa hasil studi evaluasi yang sudah dilakukan menunjukkan bahwa program UPSUS Pajale belum mampu meningkatkan produksi, seperti hasil penelitian yang dilakukan di salah satu kabupaten di Provinsi Aceh (Teuku Mizan M, Romano, 2015).

Seharusnya dengan gencarnya pelaksanaan UPSUS Pajale hampir di seluruh wilayah provinsi Indonesia apa bisa menambah sentralsentral produksi pajale jika dibandingkan sebelum adanya program tersebut. Karena seharusnya dengan gencarnya pelaksanaan program tersebut akan menambah produksi padi, jagung dan kedelai sebagai akibat meningkatnya daerah-daerah sentral produksi komoditi tersebut.

Oleh karena itu penelitian ini bertujuan untuk (1) menganalisis provinsi-provinsi yang menjadi basis komoditi pajale sebelum dan setelah program UPSUS Pajale, (2) menganalisis 
terjadinya penyebaran dan pemusatan produksi komoditi pajale sebelum dan setelah program UPSUS Pajale, (3) menganalisis provinsiprovinsi yang menjadi prioritas upsus pajale sebelum dan setelah UPSUS Pajale.

\section{Metode Penelitian}

Penelitian ini menggunakan pendekatan deskriptif kuantitatif yang menggunakan data sekunder tahun 2012 - 2017 meliputi data produksi, harga komoditi dan nilai produksi komoditi padi, jagung dan kedelai. Semua provinsi di Indonesia menjadi sampel dalam penelitian ini.

\subsection{Menganalisis Provinsi-provinsi yang Menjadi Basis Komoditi Pajale Sebelum dan Setelah Program UPSUS PAJALE}

Alat analisis yang digunakan untuk menentukan provinsi-rvinsi yang menjadi basis komoditi pajale yaitu analisis Location Quotient (LQ). Menurut Propis dalam (Crawley, Beynon, \& Munday, 2013) merumuskan LQ sebagai berikut:

$L Q=\frac{x_{i} / n_{i}}{x / n}$

xi merupakan jumlah nilai produksi komoditi pajale di tingkat provinsi, ni adalah jumlah total nilai produksi komoditi pajale di tingkat provinsi i. $\mathrm{x}$ adalah jumlah nilai produksi komoditi pangan di tingkat nasional, dan $\mathrm{n}$ adalah jumlah total nilai produksi komoditi pangan di tingkat nasional. Jika nilai LQ $\geq 1$ berarti provinsi tersebut merupakan basis komoditi pajale, sedangkan jika LQ $\leq 1$ berarti provinsi tersebut bukan merupakan basis komoditi pajale (Volsi, Telles, Caldarelli, \& Camara, 2019).

2.2. Menganalisis Terjadinya Penyebaran dan Pemusatan Produksi Komoditi Pajale Sebelum Dan Setelah Program UPSUS PAJALE

Penyebaran dan pemusatan produksi komoditi pajale dianalisis dengan menggunakan Specialization dan Localization Quotient. Specialization Quotient memiliki formulasi sebagai berikut (Vaulina, 2016).

$K S=\left\{\left(\frac{S_{i}}{\sum S_{i}}\right)-\left(\frac{N_{i}}{\sum N_{i}}\right)\right\}$

$\mathrm{Si}$ merupakan nilai produksi komoditi pajale di tingkat provinsi, $\mathrm{Ni}$ adalah nilai produksi komoditi pajale di tingkat nasional, $\Sigma \mathrm{Si}$ adalah total nilai produksi komoditi pajale di tingkat provinsi dan $\Sigma \mathrm{Ni}$ adalah total nilai produksi pertanian di tingkat nasional.

Kriterianya jika $\mathrm{KS} \geq 1$ berarti komoditi pajale terspesialisasi pada suatu kabupaten, dan jika KS $<1$ berarti komoditi pajale tidak terspesialisasi di beberapa wilayah di kabupaten.

Localization Quotient digunakan untuk mengukur penyebaran (konsentrasi) relative/lokalisasi pengembangan komoditi di suatu wilayah. Formulasinya yaitu (Vaulina \& Khairizal, 2016):

$K L=\left\{\left(\frac{S_{i}}{N_{i}}\right)-\left(\frac{\sum S_{i}}{\sum N_{i}}\right)\right\}$

Kriterianya jika $\mathrm{KL} \geq 1$ berarti komoditi pajale terkonsentrasi pada suatu kabupaten, dan jika $\mathrm{KL}<1$ berarti komoditi pajale tersebar di beberapa wilayah di kabupaten. Jadi komoditi pajale prioritas ditentukan dari nilai LQ dan KS paling tinggi.

2.3. Menganalisis Provinsi-Provinsi yang Menjadi Prioritas Komoditi Pajale Sebelum dan Setelah UPSUS PAJALE

Komoditi pajale yang menjadi prioritas dianalisis berdasarkan gabungan dengan melihat nilai LQ terbesar dan KS paling tinggi dari komoditi pajale di setiap provinsi. Semakin besar nilai LQ suatu komoditi maka semakin besar pula potensi keunggulan komoditi tersebut. Dan begitu juga jika nilai kuosien spesialisasinya paling tinggi dari berbagai komoditi yang ada berarti komoditi tersebut mempunyai keunggulan komparatif untuk diproduksi di kota tersebut. Komoditi pangan yang memiliki LQ terbesar dan KS tertinggi yang dapat diprioritaskan untuk dikembangkan lebih baik lagi di suatu daerah.

\section{Hasil dan Pembahasan}

\subsection{Provinsi-provinsi yang Menjadi Basis Komoditi Pajale Sebelum dan Setelah Program UPSUS PAJALE}

Dari 34 provinsi yang dianalisis menggunakan alat analisis LQ menunjukkan bahwa terjadi penambahan provinsi basis komoditi pajale setelah adanya Program UPSUS PAJALE. Provinsi yang menjadi basis komoditi pajale ditunjukkan dengan nilai $\mathrm{LQ} \geq 1$. Ada 19 provinsi menjadi basis komoditi padi yang sebelumnya 18 provinsi, ada 11 provinsi menjadi basis jagung yang sebelumnya 10 provinsi dan 11 provinsi menjadi basis komoditi kedelai yang sebelumnya hanya 8 provinsi. 
Tabel 1. Provinsi-Provinsi Menjadi Basis Pajale (LQ $\geq 1)$ Sebelum dan Setelah Program UPSUS PAJALE

\begin{tabular}{|c|c|c|}
\hline \multirow[b]{2}{*}{ Komoditi } & \multicolumn{2}{|l|}{ Periode } \\
\hline & $\begin{array}{l}\text { Sebelum } \\
\text { Program }\end{array}$ & $\begin{array}{l}\text { Setelah } \\
\text { Program }\end{array}$ \\
\hline Padi & 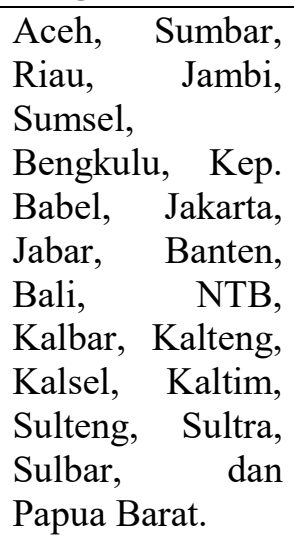 & $\begin{array}{l}\text { Aceh, Sumut, } \\
\text { Sumbar, Riau, } \\
\text { Jambi, Sulsel, } \\
\text { Bengkulu, } \\
\text { Jakarta, Jabar, } \\
\text { Banten, Bali, } \\
\text { Kalbar, } \\
\text { Kalteng, Kalsel, } \\
\text { Kaltim, Kaltara, } \\
\text { Sulteng, Sulsel, } \\
\text { dan Sultra }\end{array}$ \\
\hline Jagung & $\begin{array}{l}\text { Sumut, } \\
\text { Lampung, } \\
\text { Jateng, Jatim, } \\
\text { NTB, NTT, } \\
\text { Sulut, Sulsel, } \\
\text { Gorontalo, dan } \\
\text { Sulbar }\end{array}$ & $\begin{array}{l}\text { Sumut, Sumbar, } \\
\text { Jambi, } \\
\text { Lampung, } \\
\text { Jatim, NTT, } \\
\text { NTB, Sulut, } \\
\text { Sulsel, } \\
\text { Gorontalo, dan } \\
\text { Sulbar }\end{array}$ \\
\hline Kedelai & $\begin{array}{l}\text { Aceh, DIY, } \\
\text { Jatim, NTB, } \\
\text { Sulteng, Sulsel, } \\
\text { Papua Barat, dan } \\
\text { Papua }\end{array}$ & $\begin{array}{lr}\text { Aceh, } & \text { Jambi, } \\
\text { Jateng, } & \text { DIY, } \\
\text { Jatim, } & \text { NTB, } \\
\text { Kaltara, } & \text { Sulut, } \\
\text { Sulteng, } & \text { Sultra, } \\
\text { dan } & \text { Papua } \\
\text { Barat } & \end{array}$ \\
\hline
\end{tabular}

3.2. Penyebaran dan Pemusatan Produksi Komoditi Pajale Sebelum dan Setelah Program UPSUS PAJALE

\subsubsection{Komoditi Padi}

Penyebaran komoditi padi seperti yang ditunjukkan pada Gambar 2. bahwa nilai KS komoditi padi tidak ada yang lebih besar dari 1 $(\mathrm{KS}<1)$. Hal ini menunjukkan bahwa komoditi padi menyebar di beberapa kabupaten dalam provinsi atau bisa dikatakan tidak ada kabupaten yang terspesialisasi untuk komoditi padi.

Namun ada $50 \%$ provinsi yang memiliki komoditi padi dengan nilai KS positif dan $50 \%$ nilai KS negatif. Nilai KS positif mengindikasikan bahwa provinsi tersebut memiliki basis komparatif dalam produksi komoditi padi.

Jika dibandingkan nilai KS sebelum dan setelah program bisa dikatakan bahwa provinsi yang memiliki nilai KS positif setelah adanya program memiliki nilai KS yang lebih rendah (mendekati nol) dibandingkan sebelum adanya program. Artinya program UPSUS menambah produksi komoditi padi lebih menyebar di beberapa kabupaten dalam provinsi tersebut. Hal tersebut dibuktikan dengan meningkatnya jumlah produksi setelah adanya program UPSUS Pajale (Ponto, Jeremy; Benu, Noortje M.; Kumaat, 2017).

Seperti yang terlihat juga pada Gambar 2 . hanya ada 8 provinsi yang memiliki nilai KS yang meningkat setelah adanya program UPSUS yaitu Lampung, Jawa Tengah, Jawa Timur, Bali, Nusa Tenggara Timur, Sulawesi Tengah, Sulawesi Selatan dan Papua. Jadi 8 provinsi tersebut mendekati spesialisasi dalam produksi padi setelah adanya program UPSUS.

Nilai KS Komoditi Padi

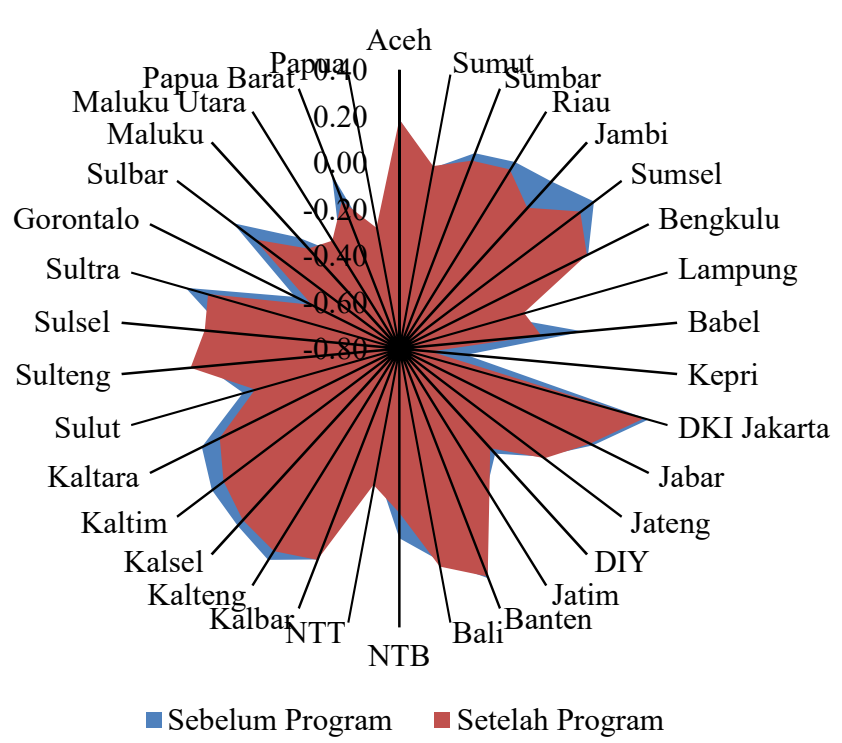

Gambar 1. Grafik Penyebaran/Spesialisasi Komoditi Padi Sebelum dan Setelah Program di Seluruh Provinsi (Hasil Analisis)

Tingkat penyebaran yang sebelumnya dijelaskan di atas, juga dikuatkan dari hasil analisis KL pada Gambar 2. yang menunjukkan terjadi atau tidaknya pemusatan komoditi padi. Dari Gambar 2. terlihat bahwa hampir semua provinsi memiliki nilai KL mendekati 0 , berarti produksi komoditi padi tidak memusat di beberapa kabupaten dalam provinsi.

Jika dibandingkan nilai KL sebelum dan setelah adanya program UPSUS di beberapa provinsi memiliki nilai KL lebih rendah dibandingkan sebelum adanya program. Hasil ini sesuai dengan analisis KS yang dibahas sebelumnya. 


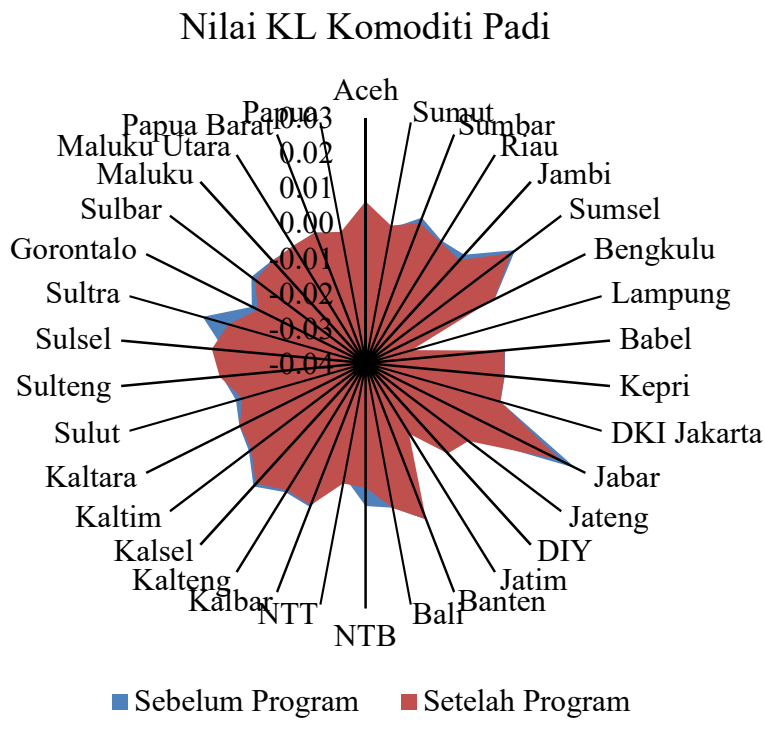

Gambar 2. Grafik Pemusatan Komoditi Padi Sebelum dan Setelah Program di Seluruh Provinsi (Hasil Analisis)

\subsubsection{Komoditi Jagung}

Komoditi jagung merupakan komoditi yang sekarang banyak digemari oleh petani di beberapa daerah di Indonesia. Bahkan berdasarkan proyeksi pada tahun 2020 produksi jagung Indonesia akan mencapai 19,1 juta ton yang tentunya produksi tersebut dipengaruhi oleh luas panen, benih, dan penggunaan benih hibrida (Sari, Hudoyo, \& Soelaiman, 2018).

Jika dilihat Gambar 3. yang menunjukkan nilai KS komoditi jagung sebenarnya belum begitu banyak diproduksi secara merata di seluruh provinsi. Karena hanya Provinsi Sulawesi Utara dan Gorontalo yang memiliki nilai KS positif (mendekati 1), artinya hanya provinsi tersebut yang memiliki basis komparatif dalam produksi komoditi jagung.

Selain dua provinsi di atas, provinsiprovinsi lainnya memiliki nilai $\mathrm{KS}$ negatif, artinya banyak provinsi yang tidak memiliki basis komparatif untuk komoditi jagung. Hal ini disebabkan karena petani masih enggan untuk berbudidaya komoditi jagung meskipun sudah ada program UPSUS pajale karena Gambaran nilai KL yang menunjukkan pemusatan produksi komoditi jagung, hasilnya tidak berbeda jauh dengan nilai KS komoditi jagung, yaitu nilai KL mendekati 0 . Artinya komoditi jagung belum ada pemusatan produksi di kabupaten-kabupaten dalam provinsi.

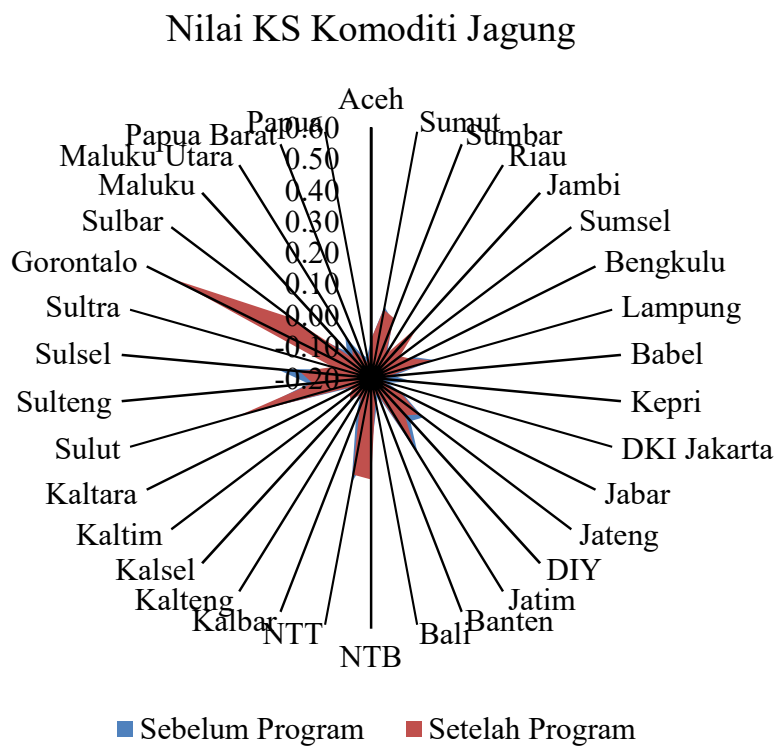

Gambar 3. Grafik Penyebaran/Spesialisasi Komoditi Jagung Sebelum dan Setelah Program di Seluruh Provinsi (Hasil Analisis)

Jika dibandingkan sebelum dan setelah adanya program UPSUS nilai KL komoditi jagung tidak banyak perubahan. Hal ini mengindikasikan bahwa program UPSUS belum mampu menambah daerah-daerah produksi komoditi jagung.

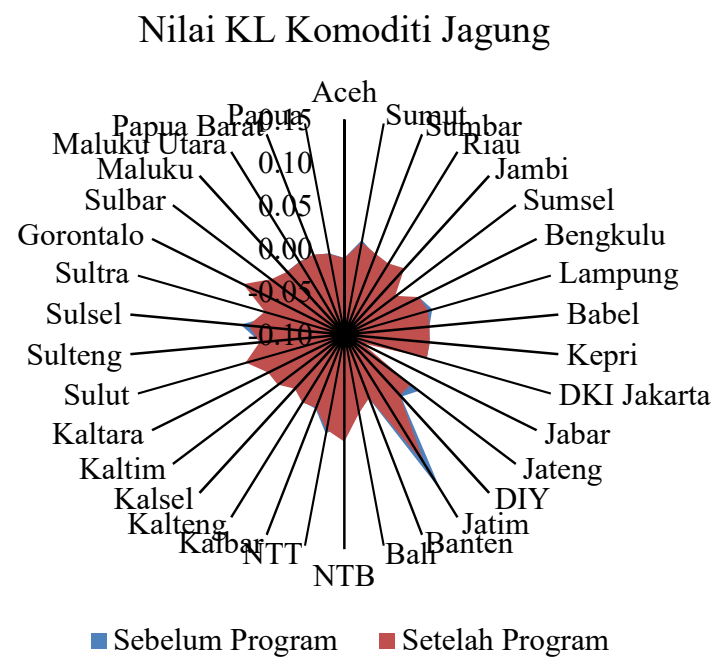

Gambar 4. Grafik Pemusatan Komoditi Jagung Sebelum dan Setelah Program di Seluruh Provinsi (Hasil Analisis)

\subsubsection{Komoditi Kedelai}

Kedelai juga menjadi komoditi priotitas untuk swasembada, meskipun saat ini komoditi kedelai Indonesia banyak di-supply dari negara luar (impor). Data dari Kementerian Pertanian pada tahun 2017 tercatat impor kedelai sebanyak 5,76 juta ton dengan nilai impor 3,3 milyar dolar. 
Dengan fakta tersebut menjadi tantangan besar bagi pemerintah untuk mewujudkan swasembada kedelai.

Berdasarkan Gambar 5. menunjukkan nilai KS komoditi kedelai hampir sama dengan nilai KS komoditi padi yang banyak provinsi yang tidak memiliki basis komparatif untuk komoditi jagung karena nilai KS negatif (mendekati nol). Hal ini bisa disebabkan karena minat petani menanam kedelai masih sangat rendah dan daya saing komoditi kedelai terhadap tanaman pangan lain atau pun kedelai impor juga sangat rendah (Hani \& Geraldine, 2007).

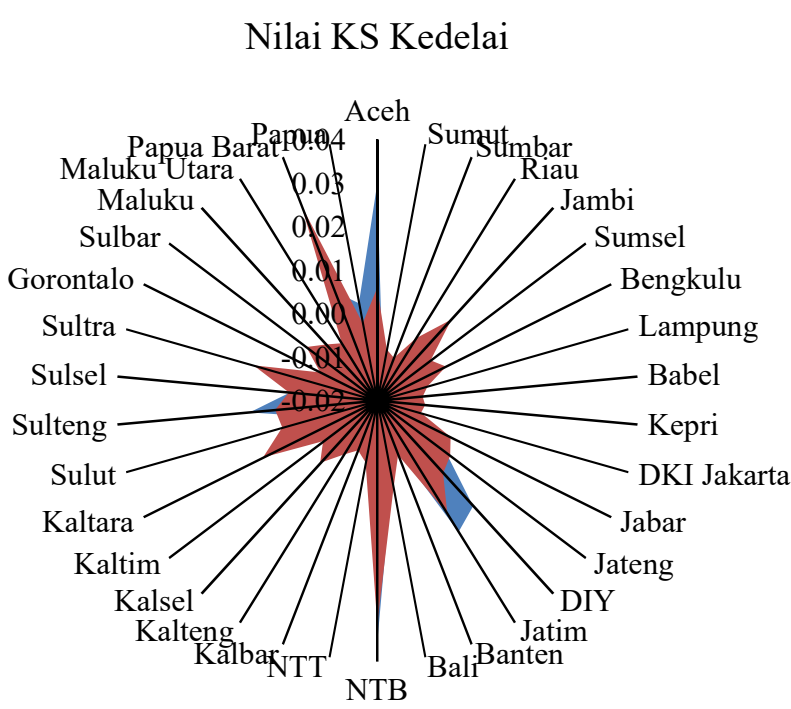

घebelum Program $\quad$ Setelah Program

Gambar 5. Grafik Penyebaran/Spesialisasi Komoditi Kedelai Sebelum dan Setelah Program di Seluruh Provinsi (Hasil Analisis)

Jika dibandingkan nilai KS sebelum dan setelah ada program UPSUS Pajale, tidak banyak perubahan pada nilai KS pada provinsi yang memiliki nilai KS negatif (mendekati nol). Perubahan terjadi hanya pada provinsi yang memiliki nilai KS positif seperti Aceh, DI Yogyakarta, Sulawesi Tengah dan Papua Barat. Di provinsi-provinsi tersebut setelah adanya program UPSUS memiliki nilai KS yang lebih rendah (mendekati nol) dibandingkan sebelum adanya program (kecuali Aceh dan Papua Barat). Artinya setelah adanya program, dapat menambah penyebaran produksi komoditi kedelai di kabupaten-kabupaten dalam provinsi tersebut.

Nilai KL komoditi kedelai sama halnya dengan nilai KS komoditi kedelai. Bisa dilihat pada Gambar 6. bahwa nilai KS komoditi kedelai di hampir semua provinsi mendekati nol. Artinya produksi komoditi kedelai belum terjadi pemusatan produksi komoditi kedelai. Jika dibandingkan sebelum dan setelah adanya program UPSUS tidak banyak perubahan di hampir semua provinsi. Perubahan hanya terjadi di Provinsi Jawa Tengah dan Nusa Tenggara Barat yang setelah adanya program nilai KS lebih rendah dibandingkan sebelumnya. Hal ini berarti di program UPSUS dapat menambah penyebaran produksi komoditi kedelai di kedua provinsi tersebut.

Nilai KL Komoditi Kedelai

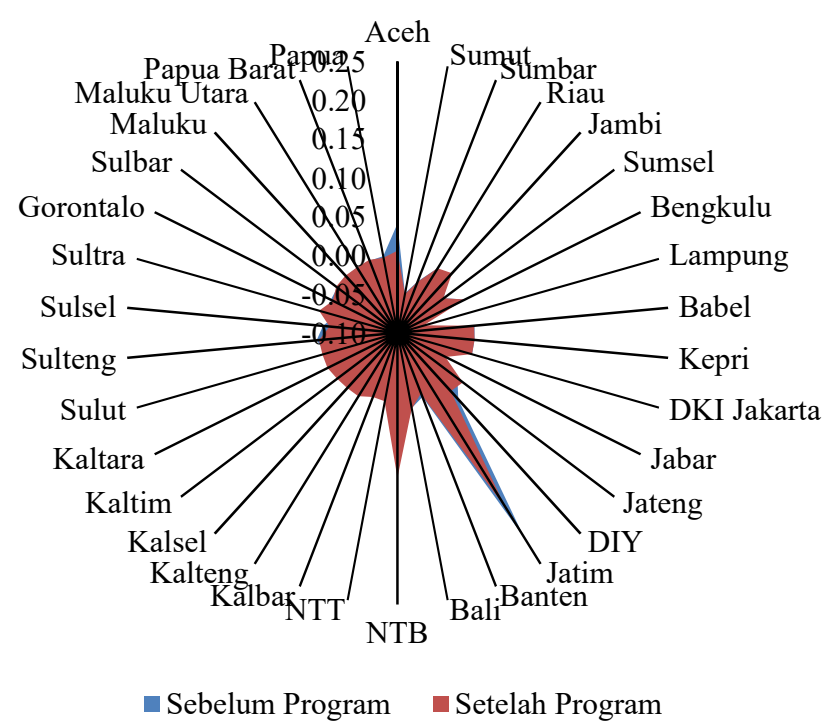

Gambar 6. Grafik Pemusatan Komoditi Kedelai Sebelum dan Setelah Program di Seluruh Provinsi (Hasil Analisis)

\subsection{Provinsi-Provinsi yang Menjadi Prioritas Komoditi Pajale Sebelum dan Setelah UPSUS PAJALE}

\subsubsection{Komoditi Padi}

Berdasarkan pertimbangan nilai $\mathrm{LQ}>1$ dan KS relatif tinggi (bernilai positif atau mendekati 1), dari Gambar 7. menunjukkan bahwa komoditi padi menjadi prioritas hampir di semua provinsi, kecuali Sumatera Utara, Lampung, Kep. Bangka Belitung, Kep. Riau, Jawa Tengah, DI Yogyakarta, Jawa Timur, Nusa Tenggara Timur, Sulawesi Utara, Gorontalo, Maluku, Maluku Utara dan Papua. Ada beberapa provinsi yang menjadi perhatian, seperti Jawa Barat, Jawa Tengah, dan Jawa Timur yang dikenal sebagai sentral lumbuh padi nasional. Namun dari hasil penelitian ini komoditi padi tidak menjadi prioritas di ketiga provinsi tersebut. Karena Jawa Barat dan Jawa Tengah menunjukkan luas tanam padi tahun 2017 
dibandingkan tahun 2016. Di Jawa Barat luas tanam padi berkurang 20.139 hektar dan Jawa Timur luas tanam berkurang 3.579 hektar (Irianto, 2018).

\section{Nilai LQ dan KS Komoditi Padi}

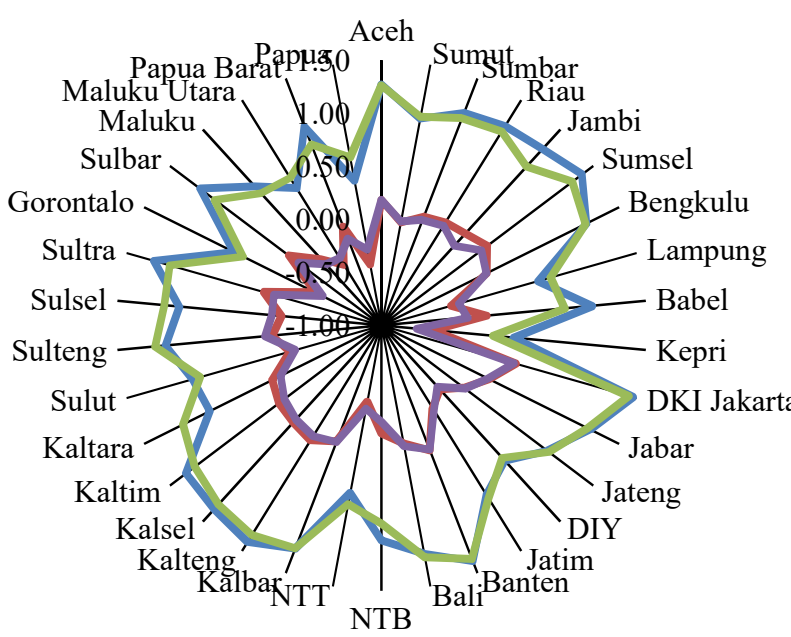

LQ Sebelum Program L LQ Setelah Program

KS Sebelum Program $\longrightarrow$ KS Setelah Program

Gambar 7. Grafik Nilai LQ dan KS Komoditi Padi Sebelum dan Setelah Program di Seluruh Provinsi (Hasil Analisis)

Jika dibandingkan provinsi-provinsi yang menjadi prioritas padi sebelum dan setelah adanya program UPSUS, hasil analisis menunjukkan bahwa tidak banyak perubahan. Ada 19 provinsi sebelum program UPSUS dan 18 provinsi setelah program UPSUS yang menjadi prioritas komoditi padi, jadi terjadi pengurangan provinsi prioritas komoditi padi. Karena dua provinsi yang sebelumnya tidak menjadi prioritas kemudian menjadi prioritas yaitu Kalimantan Utara dan Sulawesi Selatan. Di sisi lain terjadi kondisi sebaliknya, ada yang sebelumnya menjadi prioritas padi tetapi setelah adanya program UPSUS tidak lagi menjadi provinsi prioritas untuk komoditi padi seperti Nusa Tenggara Barat, Sulawesi Barat dan Papua Barat.

\subsubsection{Komoditi Jagung}

Ada dua belas provinsi yang menjadi prioritas komoditi jagung yaitu Sumatera Utara, Sumatera Barat, Jambi, Lampung, Jawa Tengah, Jawa Timur, Nusa Tenggara Barat, Nusa Tenggara Timur, Sulawesi Utara, Sulawesi Selatan, Gorontalo dan Sulawesi Barat. Jika dibandingkan provinsi prioritas komoditi jagung sebelum dan setelah adanya program. Ada 10 provinsi sebelum program UPSUS dan 11 provinsi setelah program UPSUS jadi ada penambahan 1 provinsi setelah adanya program. Hal ini terjadi karena dua penambahan dan satu pengurangan provinsi yang menjadi prioritas komoditi jagung. Provinsi Sumatera Barat dan Jambi sebagai penambah provinsi yang menjadi prioritas komoditi jagung, tetapi terjadi sebaliknya pada Provinsi Jawa Tengah yang tidak menjadi prioritas komoditi jagung setelah adanya program.
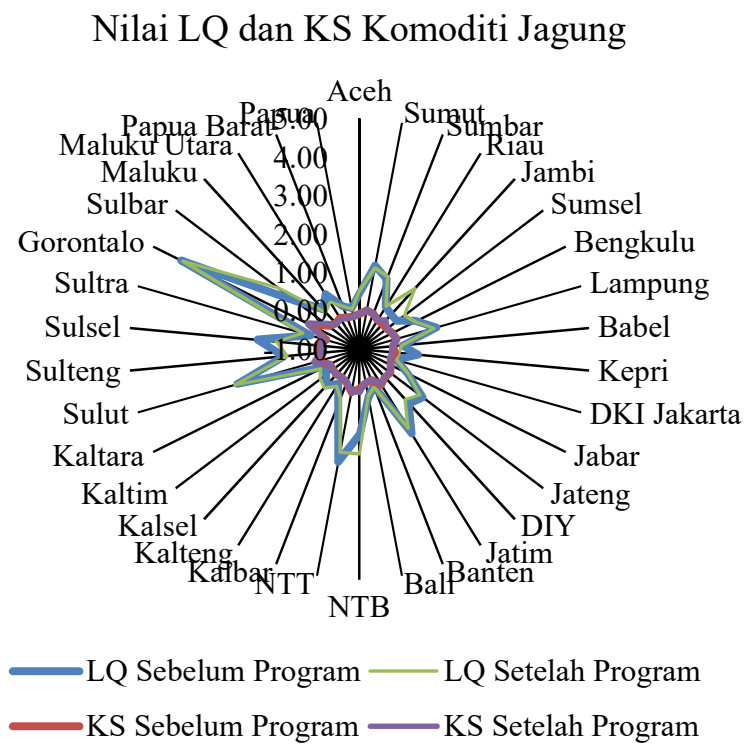

Gambar 8. Grafik Nilai LQ dan KS Komoditi Jagung Sebelum dan Setelah Program di Seluruh Provinsi (Hasil Analisis)

\subsubsection{Komoditi Kedelai}

Sebelum adanya program UPSUS Pajale ada 8 provinsi yang menjadi prioritas komoditi kedelai dan 11 provinsi setelah adanya program. Artinya ada 3 penambahan provinsi yang menjadi prioritas komoditi kedelai setelah adanya program. Karena Provinsi Jambi, Jawa Tengah, Kalimantan Utara, Sulawesi Utara dan Sulawesi Tenggara menjadi provinsi penambah menjadi prioritas komoditi kedelai setelah adanya program. Dan hanya Provinsi Papua yang setelah program tidak menjadi prioritas komoditi kedelai.

Jika diperhatikan hasil perbandingan provinsi untuk komoditi pajale sebelum dan setelah adanya program UPSUS, penambah provinsi prioritas hanya terjadi untuk satu provinsi untuk komoditi jagung dan tiga provinsi untuk komoditi kedelai. Sedangkan untuk komoditi padi terjadi sebaliknya, terjadi pengurangan satu provinsi prioritas setelah adanya program UPSUS. Ini terjadi bisa disebabkan menurunnya produksi padi karena konversi lahan sawah, musim dan sebagainya. 
Nilai LQ dan KS Komoditi Kedelai

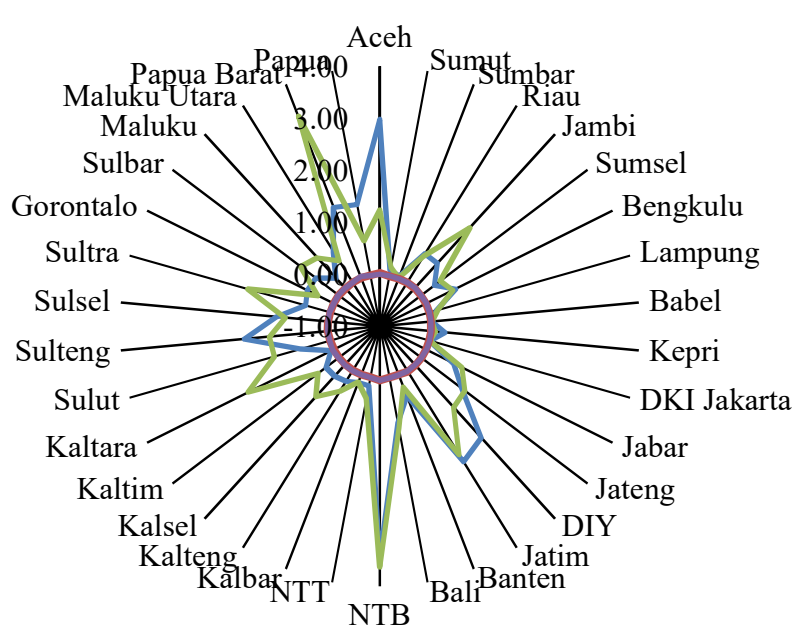

LQ Sebelum Program $\_$LQ Setelah Program
KS Sebelum Program $\_$KS Setelah Program

Gambar 9. Grafik Nilai LQ dan KS Komoditi Kedelai Sebelum dan Setelah Program di Seluruh Provinsi (Hasil Analisis)

Produksi komoditi padi, jagung dan kedelai meningkat setelah adanya program UPSUS Pajale (Krinawati, Suman, \& Saputra, 2018). Namun peningkatan produksi tersebut lebih disebabkan karena peningkatan produktivitas lahan (Saputra et al., 2018). Sehingga sebenarnya tidak terjadi penambahan daerah-daerah baru pemroduksi pajale secara signifikan. Karena pada tahun 2017 pertambahan komoditi padi, jagung dan kedelai sebanyak 351.062 ha, 132.564 ha dan 106.022 ha secara nasional. Dan sebenarnya jika program UPSUS Pajale diimplementasikan dengan baik, maka tidak hanya meningkatkan produksi saja tetapi juga mampu meningkatkan Produk Domestik Regional Bruto (PDRB) subsektor pangan (Busyra, 2016) (Krinawati et al., 2018).

\section{Kesimpulan}

Kebijakan UPSUS Pajale yang diwujudkan melalui Peraturan Menteri Pertanian No.14 Tahun 2015 yang bertujuan mempercepat pencapaiaan swasembada komoditi pajale dengan meningkatkan produksi melalui intensifikasi maupun ekstensifikasi (perluasan lahan). Berdasarkan hasil penelitian ini menunjukkan bahwa (1) ada penambahan provinsi basis pajale setelah adanya program UPSUS Pajale, (2) setelah adanya program UPSUS Pajale terjadi penyebaran dan tidak terjadi pemusatan produksi komoditi pajale di kabupaten-kabupaten dalam provinsi, dan (3) program UPSUS Pajale hanya menambah provinsi prioritas untuk komoditi jagung dan kedelai, tidak untuk komoditi padi.

\section{Ucapan Terima Kasih}

Kami mengucapkan terima kasih pihakpihak yang telah memberikan masukan dan saran dalam penelitian ini, serta rekan-rekan kerja yang pernah diajak berdiskusi untuk penelitian ini. Terutama untuk Kementerian Riset, Teknologi dan Pendidikan Tinggi yang telah mendanai penelitian ini melalui Program Penelitian dan Pengabdian Kepada Masyarakat Tahun 2018.

\section{Daftar Pustaka}

Busyra, R. G. (2016). Dampak Program Upaya Khusus (Upsus) Padi Jagung Kedelai (Pajale) Pada Komoditas Padi Terhadap Perekonomian Kabupaten Tanjung Jabung Timur. 1(1), 12-27.

Crawley, A., Beynon, M., \& Munday, M. (2013). Making Location Quotients More Relevant as a Policy Aid in Regional Spatial Analysis. Urban Studies, 50(9), 1854-1869. https://doi.org/10.1177/0042098012466601

Hani, A., \& Geraldine, L. P. (2007). Pertumbuhan Tanaman Semusim dan Manglid (Magnolia champaca) pada Pola Agroforestry. Jurnal Ilmu Kehutanan, I(2), 22-29. https://doi.org/10.1111/gcb.13051

Irianto, S. G. (2018). Evaluasi luas tanam pajale tahun 2017 dan strategi program tahun 2018.

Jonatan Lassa,. (2010). (Sage 2002), 12-14. https://doi.org/10.1080/1749951080236914 0 .

Kementan. (2016). Outlook Komoditas Pertanian SUb Sektor Tanaman Pangan.

Krinawati, E., Suman, A., \& Saputra, P. M. A. (2018). Kajian Pengaruh Program Nasional Upaya Khusus Peningkatan Produksi Padi Terhadap Kemiskinan Perdesaan di Wilayah Barat dan Timur Indonesia. Jiep, 18(1).

Nabawi, F. (2016). Pelaksanaan Fungsi Teritorial TNI-AD dalam Mendukung Program Swasembada Pangan di Kabupaten Magelang. 1-12.

Ponto, Jeremy; Benu, Noortje M.; Kumaat, R. M. (2017). UPSUS PAJALE Dalam Menunjang 
Program Swasembada Pangan ci Kabupaten Bolaang Mongondow. 13, 253260.

Saputra, M. D., Antara, M., Program, M., Agribisnis, S., Dosen, S., Studi, P., ... Universitas, P. (2018). Dampak Program Pajala Terhadap Produktivitas Padi. 25(2), 96-105.

Sari, S. P., Hudoyo, A., \& Soelaiman, A. (2018). Proyeksi Stokastik Produksi Jagung di Indonesia. 6(4), 355-359.

Sawit, M. H. (2013). Kebijakan Swasembada Beras: Keinginan Besar yang Kehilangan Fokus. Pangan, 22(2), 67-80.

Simatupang, P., \& Rusastra, I. W. (2004). Kebijakan Pembangunan Sistem Agribisnis Padi. Ekonomi Padi Dan Beras Indonesia.

Siswanto, E., Marulitua Sinaga, B., \& Harianto, . (2018). The Impact of Rice Policy on Rice Market and The Welfare of Rice Producers and Consumers in Indonesia. Jurnal Ilmu Pertanian Indonesia, 23(2), 93-100. https://doi.org/10.18343/jipi.23.2.93

Teuku Mizan M, Romano, M. U. (2015). Strategi peningkatan produksi padi melalui upsus pajale dan kontribusinya terhadap peningkatan ekonomi di kabupaten aceh besar. 147-160.

Utami, B. N. (2015). Petani Dalam Program Upaya Khusus Padi Jagung Dan. Universitas Jember, 2(10), 41-52.

Vaulina, S. K. (2016). Identifikasi Komoditi Unggulan Pada Sektor Pertanian di Kabupaten Indragiri Hilir Provinsi Riau. Jurnal Agribinsis, 18(1), 42-54.

Volsi, B., Telles, T. S., Caldarelli, C. E., \& Camara, M. R. G. da. (2019). The dynamics of coffee production in Brazil. Plos One, 14(7), e0219742. https://doi.org/10.1371/journal.pone.021974 2

Wiryanti, T. (2015). Korelasi Ekspor dan Impor Terhadap Neraca Perdagangan dan Neraca Pembayaran Indonesia Tahun 2003 - 2013. Jurnal Ilmiah Prodi Manajemen Universitas Pamulang, 2(2), 111-128. 